5 Proceedings of the Second Annual Forestry Symposium 1996: Management and Sustainable Utilization of Forest Resources, Sri Lanka, 6-7 December 1996. (Eds. Amarasekera, HS, Ranasinghe, D M S HK and Finiayson, W). Published by Department of Forestry and Environmental Science, University of Sri Jayewardenepura, Sri Lanka (1998)

\title{
EFFECT OF LIGHT AND SOIL MOISTURE ON SEEDLING LEAF ANATOMY OF LOWLAND RAIN FOREST SPECIES
}

\author{
H.K. Gamage', B.M.P. Singhakumara ${ }^{1}$ and P.M.S. Ashton ${ }^{2}$ \\ ${ }^{\mathrm{I}}$ Department of Forestry and Environmental Science, \\ University of Sri Jayawardenapura \\ ${ }^{2}$ School of Forestry and Environmental Studies, Yale University
}

\begin{abstract}
Seedlings of Dipterocarpus zeylanicus Thw., D. hispidus_Thw., Mesua ferrea $L$., and M. nagassarium (Burm. f.) Kosterm., were grown under light treatments, three of which simulated the radiation experienced by the forest understorey and forest edge, two of which simulated the centres of canopy openings of 200 and $400 \mathrm{~m}^{2}$, and a control simulated full sunlight. For each light treatment the soil was cither regularly watered to field capacity or kept at $30 \%$ of field capacity. After two years measurements were made of stomatal frequency; of the thicknesses of the leaf-blades and of the upper epidermal, palisade mesophyll, and lower epidermal cell layers; and of cell dimensions. Significant differences were found between species and treatments. In general the measured dimensions increased with increase in light and decrease in soil moisture. Mesua ferrea had the thickest leaf blades followed by M. nagassarium, D. zeylanicus and D. hispidus, while D. zeylanicus had thicker epidermal and palisade mesophyll than $M$. ferrea; taken together, these findings suggest that $M$. ferrea has a much thicker mesophyll than the other species. In certain treatments, the two Dipterocarpus species had double rows of cells within both the palisade mesophyll and the lower epidermal layers; the frequency of this phenomenon increased with increasing light. It was not observed in Mesua, The greatest densities of stomata were found in D. hispidus, followed by $M$. ferrea, $M$. nagassarium, and D. zeylanicus. Differences in shade and drought tolerance between species are discussed.
\end{abstract}

\section{Introduction}

Within a forest there are different microenvironments due to disturbances of the canopy. The type, size and periodicity of disturbance affect the nature of the ground storey (Ashton, Gunatilleke \& Gunatilleke, 1993). When disturbances create canopy openings in moist tropical forests they allow understorey vegetation to survive. Many tropical rain forest tree species seem to depend on canopy openings, or to benefit from them, for successful regeneration (Popma \& Bongers, 1988). Depending upon the size of the opening, there will be changes in the temperature, relative humidity, amount and 
quality of light. and availability of soil moisture can change. Seedlings in the ground storey must respond to these changes in order to survive and grow.

These microenvironmental changes affect the anatomy and morphology of seedling leaves (Wilson \& Cooper, 1969). The ability of seedling leaves to change their anatomy and morphology in response to change in environment has been termed phenotypic plasticity (Young \& Giese, 1990). For example, seedling leaves that are exposed to more light have physiological and anatomical adaptations similar to those of droughtavoiding plants, whilc shade leaves often resemble those of drought-intolerant species. Shade leaves are larger and thinner, while sun leaves are smaller and thicker (Transeau et al., 1940; Jackson, 1966: Vogel 1968: Nobel, 1977: Kramer, 1983; Keller et al., 1987).

Many studies have shown that leaf anatomy and morphology differ between tree specics categorized on the one hand as pioncers and late-successional, or on the other hand as sun-loving and shade-tolerant (Carpenter \& Smith, 1975; Fetcher et al., 1983; Vogel, 1968; Loach, 1967). Few studies have looked for different changes in leaf structure among tree species considered to belong to the same ecological grouping. eg. the same successional or the same light-tolerance status (Ashton \& Berlyn, 1992). No studies have investigated changes within a given ecological grouping that has been grown under differing soil-moisture availability.

Our study examined the adaptation of secdling leaves of four species of canopy trees: Dipterocarpus zeylanicus Thw., $D$ hispidus Thw. Mesua ferrea L., and $M$. nagassarium (Burm.f.) Kosterm., that occur in the rain forest of southwest Sri Lanka, and that have all been characterized as late-successional and rclatively shade tolerant. We tested the hypotheses that anatomical attributes of seedling leaves can be modified by growing them under different light intensities and soil moisture regimes such as are experienced in the forest.

\section{Study site, species, and methods}

\section{Study site}

The study was made at the field station of the Sinharaja Man and the Biosphere (MAB) Reserve in southwest Sri Lanka. The annual rainfall is about $5000 \mathrm{~mm}$, and the mean monthly temperatures range from 25 to $27^{\circ} \mathrm{C}$ (Ashton, 1992). The topography is undulating between valley bottoms and ridge tops, with a mean elevation of about 600 m. The forest has been classified by De Rosayro (1942) and Ashton \& Gunatilleke (1987) as a Mesua-Shorea type.

\section{Species}

The four species are endemic to southwest Sri Lanka. They are often dominant in the canopy stratum of late-successional forest. Both D. zeylanicus and D. hispidus are widespread below $300 \mathrm{~m}$ (Dassanayake, 1980; FAO, 1985). They are often gregarious on river banks and moist but well drained soils. Mesua ferrea occurs in or near streams,

\section{0}


but not on low-lying poorly drained land. Mesua nagassarium is generally restricted to ridge tops.

\section{Experimental design}

Six controlled-environment shelters were constructed. The quality of light was altered by using a mix of particular pigments in a varnish base that was sprayed onto a clear plastic film. Three light treatments exposed seedlings to uniform diffuse light that simulated the amount and quality of radiation in the forest understorey (FU), inside the forest edge ( $\mathrm{FE})$, and outside the forest edge (OE). The maximum photon photosynthetic fluxes (PPFD) for the treatments were respectively 50,350 and 800 mmol $\mathrm{m}^{-2} \mathrm{~s}^{-1}$ ). Two other light treatments exposed seedlings to amounts of direct radiation that were comparable to the centres of canopy openings of $100 \mathrm{~m}^{2}$ (SO) and $400 \mathrm{~m}^{2}(\mathrm{LO})$; these conditions were created by a scries of parallel vertical slats, $1.5 \mathrm{~m}$ above the seedlings. While the sun rose from the east and set in the west the duration and number of sunlit periods were controlled by the slat orientation being north-south, at varying spacings. A control treatment exposed seedlings to full sun (FS), with a maximum PPFD of $2000 \mathrm{mmol} \mathrm{m}^{-2} \mathrm{~s}^{-1}$ ).

Within each light treatment there were two watering treatments. The ever-moist soil condition $(100 \%$ relative moisture content. $\mathrm{RMC})$ received two litres of water per $\mathrm{m}^{2}$ three times a week. The dry soil condition received two litres of water per $\mathrm{m}^{2}$ whenever the $\mathrm{RMC}$ fell below $30 \%$. In each regime the RMC was monitored by a battery-operated soil-moisture meter (Bouyoucos, 1953, 1972) that was attached to gypsum blocks buried in the soil.

For each specics the sceds wcre a mix, collected from more than one parcnt trees. They were germinated on a nursery bed. In January 1993, when the seedlings were one month old, they were taken from the nursery and planted in the shclters, in forest topsoil mixed with an equal quantity of sand. Seedlings of each species were placed together in groups of nine. Four groups of seedlings, each group of a different species, comprised a block. There were four blocks for cach light-soil moisture combination, so that altogether each species-light-soil moisture combination had four replicates.

\section{Anatomical measurements}

When the seedlings were two years old, samples were taken. For each light-soil moisture combination a leaf was taken from each of three different seedlings for each species. All the selected leaves were fully expanded, undamaged and with no signs of herbivory. Permanent microscope slides were prepared. For each leaf, a $0.5 \times 1-\mathrm{cm}$ section was taken from the middle portion of the lamina, across the midrib. These strips were immediately fixed in FAA (formalin, acetic acid and ethanol), dehydrated in ethanol, immersed in a xylene series, and then embedded in wax. A rotary microtome was used to cut sections $10 \mathrm{~mm}$ thick. They were stained with safranine and fast green and then mounted in Canada balsam (Berlyn \& Miksche, 1976). Three slides were made from each strip. 
On each slidé, measurements were made of leaf-blade thickness and component dimensions (palisade cell height, palisade layer thickness, proportion of palisade cells double layered, upper and lower epidermal cell heights, and lower epidermal cell layer thickness). Six measurements were made on each slide for each parameter, avoiding the region of the midrib, by viewing through a Leitz light microscope with a $0.05 \times 100$ $\mathrm{mm}$ micrometer eye-piece and a $0.01 \times 100 \mathrm{~mm}$ objective. Cell dimen-sion measurements were taken at $400 \times$ magnification and leaf thickness dimensions at $100 \times$.

For D. zeylanicus and $M$. nagassarium, stomatal frequencies were observed from cellulose acetate positives of silicone-rubber impressions (Heichel, 1971). In M. ferrea the stomata are chambered, and D. hispidus has hairs on the leaf under-surface; peels were therefore taken for these species and boiled with alcohol in order to observe the stomata. Each impression or peel was taken midway between the base and tip on the upper and lower surfaces of a leaf. Five impressions or peels were used for each species and light-soil moisture combination. For each impression or peel, three different fields of view were sampled. The stomata were counted with an eye-piece graticule, at $400 \times$ magnification

\section{Data analysis}

Data were analysed by ANOVA, using the general linear model (GLM) procedure of Statistical Analysis Systems (SAS, see Ray, 1981). The analyses tested for differences between species, light treatments, soil moisture treatments and for interactions between species and treatments. Differences between the treatments and species were determined at the 5\% significance level by Tukey's method.

\section{Results}

In all cases, in both text and tables, "significant(ly)" means at $P<0.05$.

\section{Stomatal frequency}

In all four species stomata were found only on the lower surface; this finding corroborates many other studies of tree species (Metcalfe \& Chalk, 1965) (Table 1, Figure 1). Stomatal frequency increased with increasing light intensity, and thus the greatest frequency was in leaves exposed to full sun. Differences between species were also apparent within the same light treatment. Dipterocarpus hispidus had a higher stomatal frequency than $D$. zeylanicus. The two species of Mesua had similar frequencies in some light treatments, but overall $M$. ferrea had more than $M$. nagassarium. Comparing all four species, D. hispidus had the greatest frequency, followed by $M$. ferrea, M. nagassarium and D. zeylanicus. In about three quarters of the comparisons of seedlings grown in ever-moist with those in dry soils, stomatal frequency was significantly different for the same species and the same light treatment. 

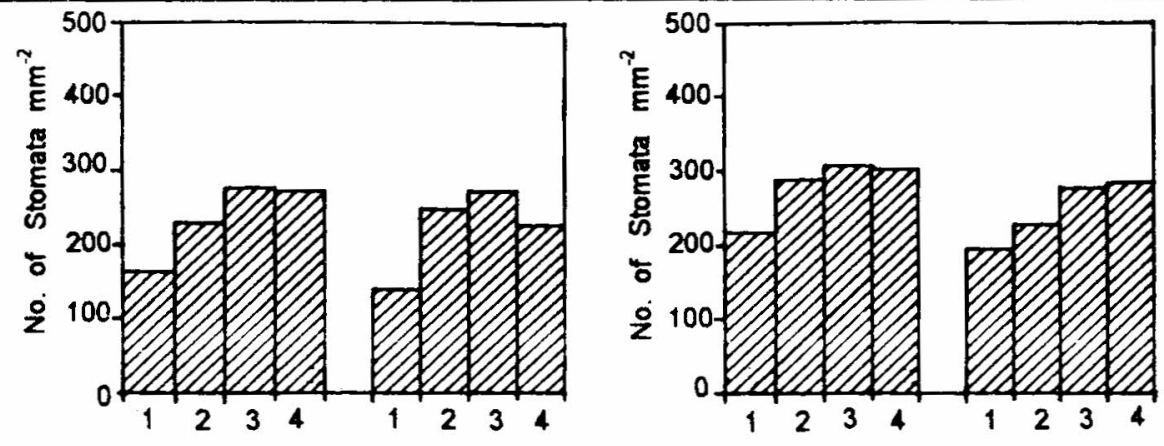

FU
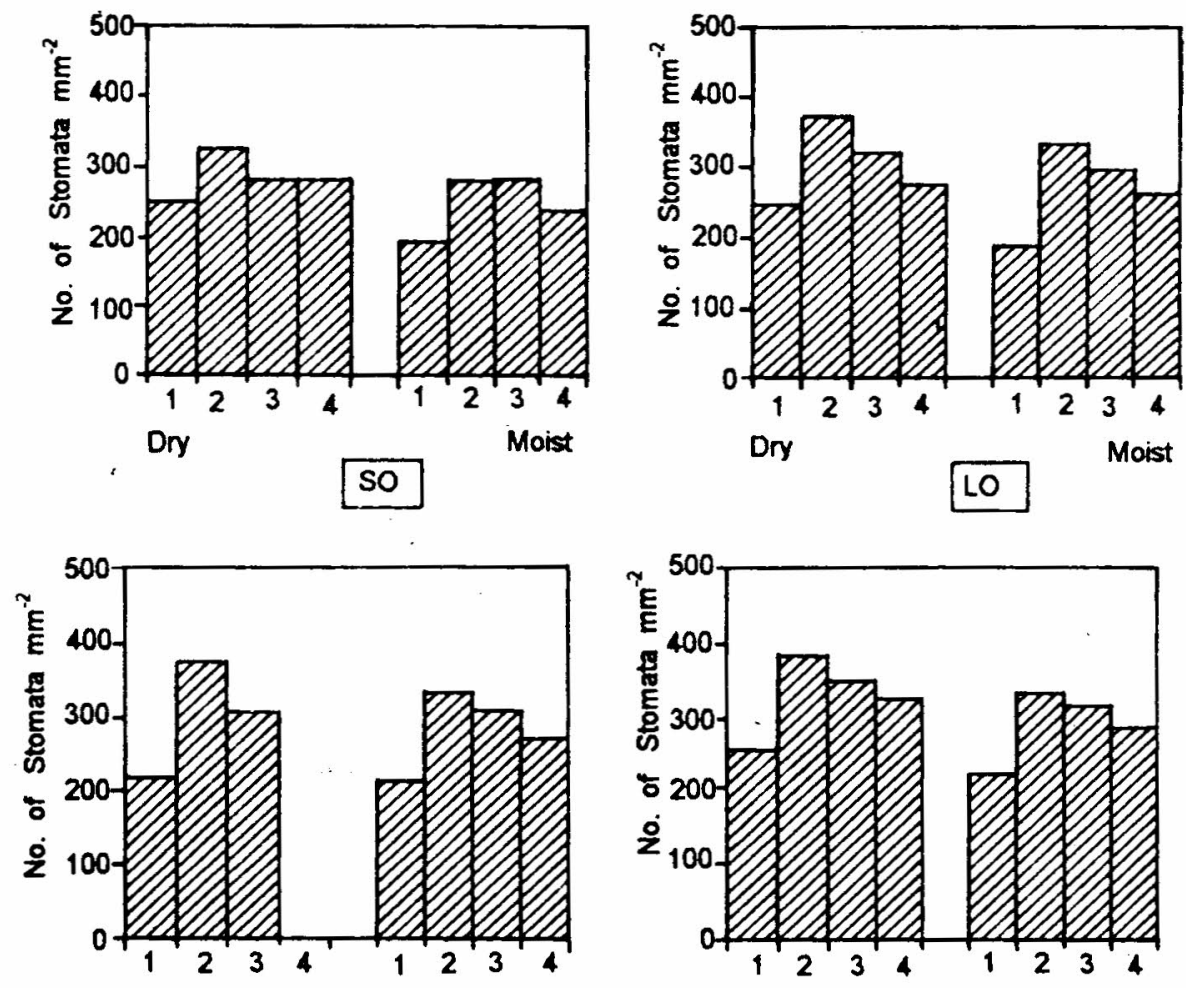

$O E$

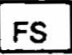

Figure 1: Stomatal frequency of leaves in (1) D. zeylanicus, (2) D. hispidus, (3) M. ferrea, and (4) $M$. nagassarium, under different light and soil-moisture treatments (FU $=$ forest understorey; $F E=$ inside forest edge; $\mathrm{OE}=$ outside forest edge; $F S=$ full sun; $\mathrm{SO}=$ centre of small opening; $\mathrm{LO}=$ centre of large opening)

In all tables:

$F U=$ forest understorey; $F E=$ inside forest edge; $O E=$ outside forest edge; $F S=$ full sun; $S O=$ centre of small opening; $L O=$ centre of large opening. 


\section{Table 1 : Stomatal frequency}

Data are the mean number per $\mathrm{mm}^{2}$ from different leaves, with standard errors in parentheses. A lower case $a$ after one figure and $b$ after the other denotes a significant difference between the soil-moisture treatments in the same species and light treatment. The capital letters before the figures denote differ-ences between species in each light treatment. Species with the same letter are not significantly different.

\begin{tabular}{|c|c|c|c|}
\hline & & Dry & Moist \\
\hline \multicolumn{4}{|l|}{ FU } \\
\hline D. zeylamicus & B & $162.2(1.3) \mathrm{a}$ & $140.0(7.8) b$ \\
\hline D. hispidus & A & $226.7(16.7) b$ & $247.4(12.7) \mathrm{a}$ \\
\hline M. ferrea & A & $275.6(9.2) \mathrm{a}$ & $271.8(9.0) \mathrm{a}$ \\
\hline M. nagassarium & A & $270.4(14.8) a$ & $225.9(13.0) \mathrm{b}$ \\
\hline \multicolumn{4}{|l|}{ FE } \\
\hline D. zeylanicus & $\mathrm{B}$ & $212.6(8.7) \mathrm{a}$ & $191.1(6.4) \mathrm{a}$ \\
\hline D. hispidus & A & $282.2(21.8) \mathrm{a}$ & $224.4(8.01) b$ \\
\hline M. ferrea & A & $300.7(7.1) \mathrm{a}$ & $271.8(4.5) b$ \\
\hline M. nagassarium & A & $296.30(20.5) \mathrm{a}$ & $241.5(9.5) \mathrm{b}$ \\
\hline \multicolumn{4}{|l|}{ OE } \\
\hline D. zevlanicus & $\mathrm{C}$ & $213.3(14.3) \mathrm{a}$ & $207.4(7.8) \mathrm{a}$ \\
\hline D. hispidus & A & $369.6(8.2) \mathrm{a}$ & $328.2(5.8) b$ \\
\hline M. ferrea & $B$ & $303.0(4.9) \mathrm{a}$ & $304.4(5.6) \mathrm{a}$ \\
\hline M. nagassarium & & NA & $266.7(14.8)$ \\
\hline \multicolumn{4}{|c|}{2504,49} \\
\hline D. zeylanicus & C & $250.4(11.2) \mathrm{a}$ & $215.6(16.8) b$ \\
\hline D. hispidus & $A$ & $380.7(8.2) a$ & $331.8(22.1) \mathrm{b}$ \\
\hline M. ferrea & $\mathrm{AB}$ & $345.2(8.5) \mathrm{a}$ & $314.1(7.1) b$ \\
\hline M. nagassarium & $\mathrm{B}$ & $322.2(3.4) \mathrm{a}$ & $283.7(5.8) b$ \\
\hline \multicolumn{4}{|c|}{$2444(118)$} \\
\hline D. zeylanicus & B & $244.4(11.8) \mathrm{a}$ & $190.4(12.1) b$ \\
\hline D. hispidus & A & $318.5(17.3) \mathrm{a}$ & $274.1(20.8) b$ \\
\hline M. ferrea & A & $276.3(3.7) \mathrm{a}$ & $274.8(10.7)$ a \\
\hline M. nagassarium & $\mathrm{AB}$ & $274.8(15.7) \mathrm{a}$ & $236.3(13.5) \mathrm{a}$ \\
\hline \multicolumn{2}{|c|}{$191 / 90) \mathrm{b}$} & $245.9(10.0) \mathrm{a}$ & $191.1(9.0) b$ \\
\hline D. zeylanicus & A & $375.6(8.4) \mathrm{a}$ & $332.6(7.3) b$ \\
\hline D. hispidus & $\mathrm{B}$ & $320.0(7.7) \mathrm{a}$ & $297.8(10.2) b$ \\
\hline M. ferrea & $\mathrm{C}$ & $275.6(1.3) \mathrm{a}$ & $264.4(7.2) \mathrm{a}$ \\
\hline M. nagassarium & & & \\
\hline
\end{tabular}




\section{Leaf-blade thickness}

Leaf-blade thickness increased with increase in light (Table 2, Fig.2), and for all species the thickest leaf blade was observed in the full-sun treatment. In most cases, differences between species were significant within the same light treatment. In Dipterocarpus the thicker leaf blades were observed in D. zeylanicus. In Mesua, the thickness was not significantly different between the two species within the same light treatment. excepting LO and SO, in which M. ferrea had the thicker blade. Mesua species had thicker leaf blades than Dipterocarpus species; when comparing all species together, the order was $M$. ferrea, M. nagassarium, D. zeylanicus, and D. hispidus.

In most instances significant differences in leaf-blade thickness could not be observed between ever-moist and dry soil treatments. The main exception was the understorey light intensity treatment (FU), in which $D$. zevlanicus, $M$. ferrea and $M$. nagassariam showed differences. These species had thicker blades when grown in the ever-moist soil treatment than when grown in the dry soil.

\section{Component dimensions}

The different light and soil-moisture treatments showed significant differences between epidermal cell thicknesses. These differences were apparent for both upper (Table 3, Fig. 3) and lower (Table 4) epidermal cells. Both upper and lower epidermal cell height were greatest in FS treatment $\left(2000 \mathrm{mmol} \mathrm{m}^{-2} \mathrm{~s}^{-1}\right)$.

Of the two dipterocarps, D. zeylanicus had the greater upper epidermal cell thickness. In Mesua both species were usually similar within the same light treatment. The dipterocarps had significantly thicker upper epidermal cells than the Mesua species.

In most cases, lower epidermal cell thickness was significantly different between species for any given light treatment. D. zevlanicus had the greatest, followed by $D$. hispidus, M. ferrea and $M$. nagassarium. Mesua ferrea had a papillated lower epidermal cell layer with sunken stomata. In almost all comparisons for any species between evermoist and dry soils differences in lower epidermal cell thicknesses were not significant. The same was also generally the case for comparisons of upper epidermal cell thickness between ever-moist and dry soil treatments. Where it was not the case, the dry soil treatment usually showed greater cell dimensions than the ever-moist soil treatment.

In the higher light treatments both dipterocarps had double rows of lower epidermal cells, while Mesua did not. This feature could be observed to a decreasing extent, in the order $\mathrm{FS}>\mathrm{LO}>\mathrm{OE}>\mathrm{SO}$. D. zeylanicus had a thicker epidermal cell layer than $D$. hispidus for each light treatment. With few exceptions, when grown in the same light treatment the lower epidermal layer thicknesses of the dipterocarps did not change significantly, between ever-moist and dry soil treatments. 


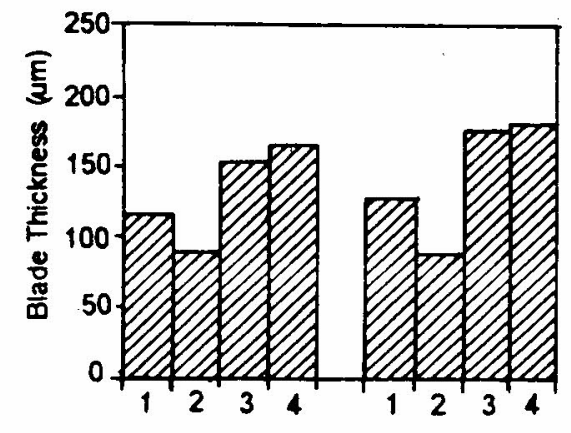

FU
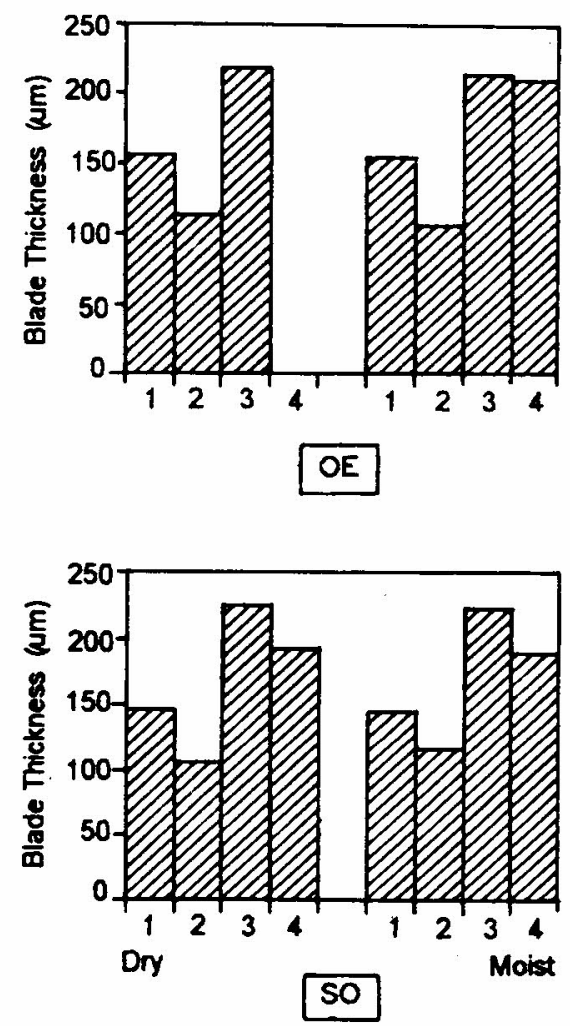
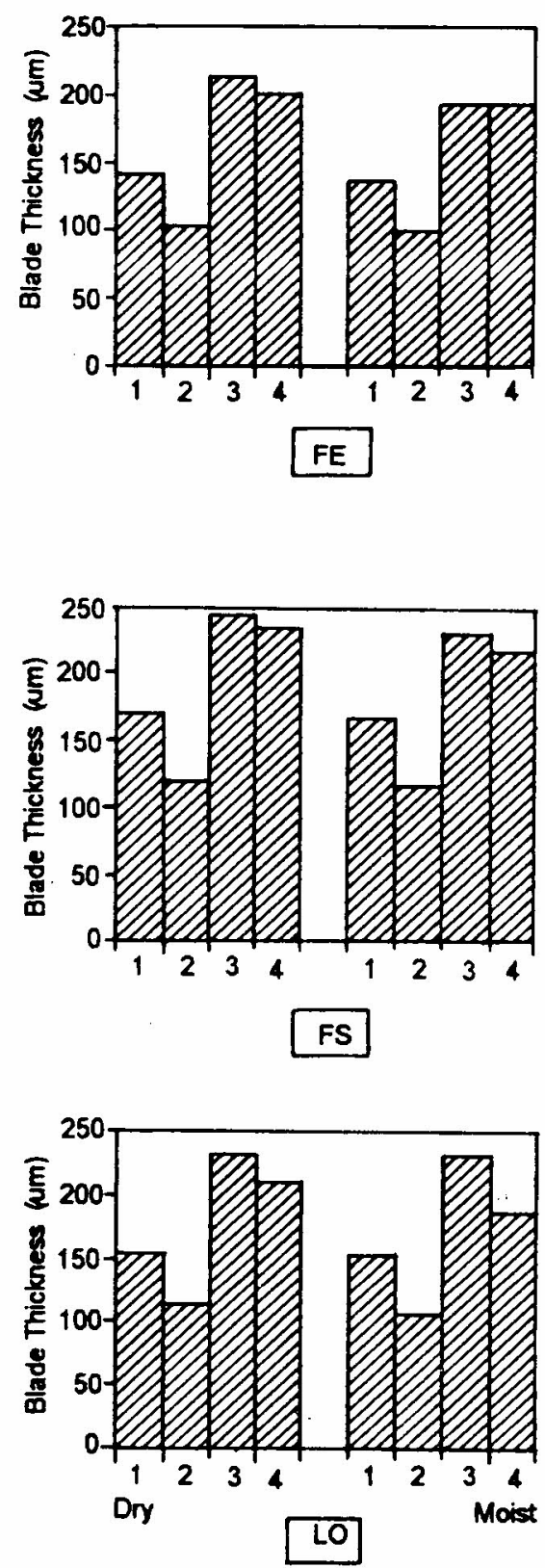

Figure 2 : Leaf-blade thickness of (1) D. zeylanicus, (2) D. hispidus, (3) M. ferrea, and (4) $M$. nagassarium, under different light and soil-moisture treatments (as in Fig. 1) 
Table 2: Leaf-blade thickness

Data are means (in $\mu \mathrm{m}$ ) from different leaves, with standard errors in parentheses. A lower case a after one figure and $b$ after the other denotes a significant difference between the soil-moisture treatments in the same species and light treatment. The capital letters before the figures denote differences between species in each light treatment. Species with the same letter are not significantly different.

\begin{tabular}{|c|c|c|c|}
\hline & & Dry & Moist \\
\hline \multicolumn{4}{|l|}{ FU } \\
\hline D. zeylanicus & B & $113.9(2.1) \mathrm{b}$ & $126.1(3.4) \mathrm{a}$ \\
\hline D. hispidus & $\mathrm{C}$ & $85.3(5.0) \mathrm{a}$ & $85.6(1.6) \mathrm{a}$ \\
\hline M. ferrea & A & $151.1(0.9) \mathrm{b}$ & $173.9(3.9) \mathrm{a}$ \\
\hline M. nagassarium & A & $162.6(3.4) \mathrm{b}$ & $179.4(0.7) \mathrm{a}$ \\
\hline \multicolumn{4}{|l|}{ FE } \\
\hline D. zeylanicus & B & $138.7(2.8) \mathrm{a}$ & $133.5(0.9) \mathrm{a}$ \\
\hline D. hispidus & C & $99.2(2.4) \mathrm{a}$ & $96.1(1.2) \mathrm{a}$ \\
\hline M. ferrea & A & $209.2(2.2) \mathrm{a}$ & $189.2(2.0) b$ \\
\hline M. nagassarium & A & $197.8(4.2) \mathrm{a}$ & $189.3(4.0) \mathrm{a}$ \\
\hline \multicolumn{4}{|l|}{ OE } \\
\hline D. zeylanicus & B & $152.9(2.5) \mathrm{a}$ & $150.7(1.5) \mathrm{a}$ \\
\hline D. hispidus & $\mathrm{C}$ & $109.1(6.5)$ a & $102.7(2.7) \mathrm{a}$ \\
\hline M. ferrea & A & $215.0(3.8) \mathrm{a}$ & $210.3(2.0) \mathrm{a}$ \\
\hline M. nagassarium & & NA & $205.8(2.2)$ \\
\hline \multicolumn{4}{|l|}{ FS } \\
\hline D. zeylanicus & B & $163.9(2.8) \mathrm{a}$ & $161.1(2.5) \mathrm{a}$ \\
\hline D. hispidus & $\mathrm{C}$ & $114.9(2.6) \mathrm{a}$ & $112.1(4.8) \mathrm{a}$ \\
\hline M. ferrea & A & $238.4(10.7) \mathrm{a}$ & $224.6(2.1) \mathrm{b}$ \\
\hline M. nagassarium & A & $228.9(2.9) \mathrm{a}$ & $209.9(1.6) b$ \\
\hline \multicolumn{4}{|l|}{ So } \\
\hline D. zeylanicus & $\mathrm{C}$ & $143.5(5.9) \mathrm{a}$ & $141.9(4.7) \mathrm{a}$ \\
\hline D. hispidus & D & $102.4(0.7) \mathrm{a}$ & $112.5(3.9) \mathrm{a}$ \\
\hline M. ferrea & A & $220.9(3.1) \mathrm{a}$ & $218.2(6.4) \mathrm{a}$ \\
\hline M. nagassarium & B & $187.7(1.5) \mathrm{a}$ & $184.4(2.6) \mathrm{a}$ \\
\hline \multicolumn{4}{|l|}{ LO } \\
\hline D. zeylanicus & C & $151.0(6.7) \mathrm{a}$ & $150.5(4.9) \mathrm{a}$ \\
\hline D. hispidus & D & $109.6(2.9)$ a & $103.9(1.5) \mathrm{a}$ \\
\hline M. ferrea & A & $228.2(0.8) \mathrm{a}$ & $229.1(1.4) \mathrm{a}$ \\
\hline M. nagassarium & B & $206.8(8.4)$ a & $185.2(4.2) \mathrm{b}$ \\
\hline
\end{tabular}




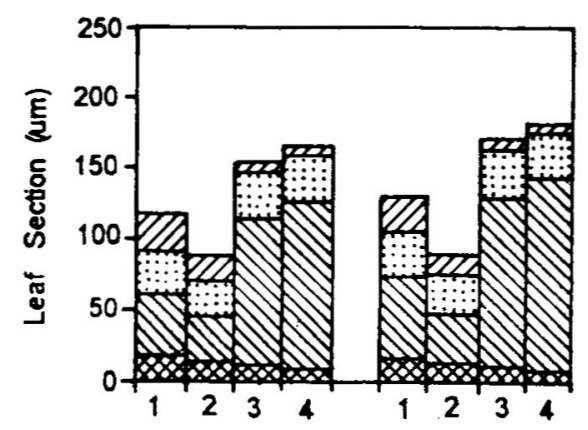

FU

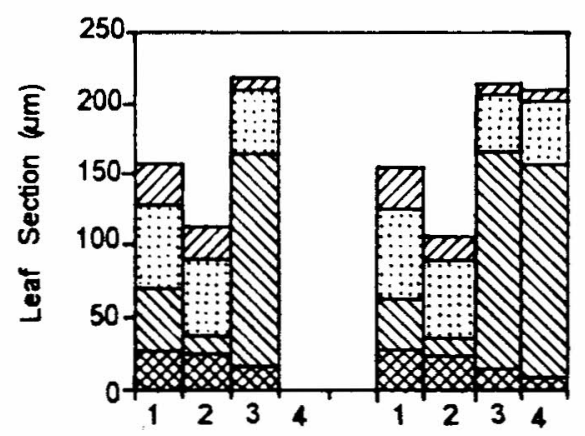

OE

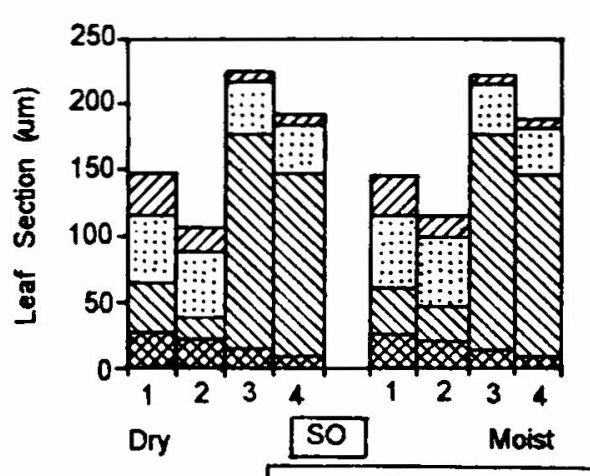

Lower Epidermis

[:: Palisade Mesophyll UD

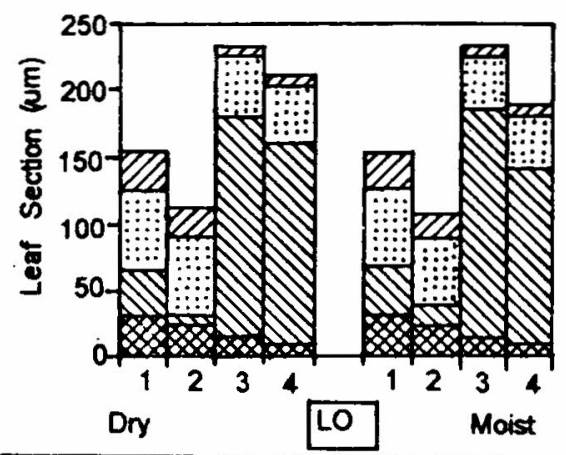

Spongy Mesophyll Upper Epidermis

Figure 3 : Stylized leaf cross-sections of (1) D. zeylanicus, (2) D. hispidus, (3) M. ferrea, and (4) $M$. nagassarium, under different light and soil moisture treatments (as in Fig. 1) 
Tahle 3 : Upper epidermal cell thickness

Data are means (in $\mu$ m) from different leaves, with standard errors in parentheses. A lower case a after one figure and $b$ after the other denotes a significant difference between the soil-moisture treatments in the same species and light treatment. The capital letters before the figures denote differ-ences between species in each light treatment. Species with the same letter are not significantly different.

\begin{tabular}{|c|c|c|c|}
\hline & & Dry & Moist \\
\hline \multicolumn{4}{|l|}{$\mathbf{F U} \quad b$} \\
\hline D. zeylanicus & A & $25.6(1.3) \mathrm{a}$ & $25.3(0.4) \mathrm{a}$ \\
\hline D. hispidus & B & $18.0(0.4) \mathrm{a}$ & $14.6(0.7) b$ \\
\hline M. ferrea & $\mathrm{C}$ & $7.3(0.3) a$ & $7.5(0.7) \mathrm{a}$ \\
\hline M. nagassarium & $\mathrm{C}$ & $6.4(0.1) b$ & $6.8(0.1) \mathrm{a}$ \\
\hline \multicolumn{4}{|l|}{ FE } \\
\hline D. zeylanicus & A & $30.0(0.5) \mathrm{a}$ & $26.9(0.4) b$ \\
\hline D. hispidus & B & $20.5(0.4) \mathrm{a}$ & $16.0(0.4) \mathrm{b}$ \\
\hline M. ferrea & $\mathrm{C}$ & $8.1(0.1) \mathrm{a}$ & $7.2(0.1) \mathrm{a}$ \\
\hline M. nagassarium & $\mathrm{C}$ & $8.6(0.3) \mathrm{a}$ & $7.8(0.2) \mathrm{a}$ \\
\hline \multicolumn{4}{|l|}{ OE } \\
\hline D. zeylanicus & A & $29.3(0.6) \mathrm{a}$ & $30.0(1.2) \mathrm{a}$ \\
\hline D. hispidus & B & $22.8(1.3) \mathrm{a}$ & $16.6(0.3) \mathrm{b}$ \\
\hline 1. ferrea & $\mathrm{C}$ & $8.4(0.3) \mathrm{a}$ & $7.6(0.3) \mathrm{a}$ \\
\hline M. nagassarium & $\mathrm{C}$ & NA & $7.7(0.1)$ \\
\hline \multicolumn{4}{|l|}{ FS } \\
\hline D. zeylanicus & A & $33.2(1.3) \mathrm{a}$ & $32.2(0.9) \mathrm{a}$ \\
\hline D. hispidus & B & $22.9(1.3) \mathrm{a}$ & $17.9(0.5) b$ \\
\hline M. ferrea & $\mathrm{C}$ & $9.8(0.0) \mathrm{a}$ & $8.2(0.1) b$ \\
\hline M. nagassarium & $\mathrm{C}$ & $8.3(0.1) \mathrm{a}$ & $8.4(0.1) a$ \\
\hline \multicolumn{4}{|l|}{ So } \\
\hline D. zeylanicus & A & $30.9(1.2) \mathrm{a}$ & $29.4(3.3) \mathrm{a}$ \\
\hline D. hispidus & B & $18.4(1.3) \mathrm{a}$ & $16.7(0.6) \mathrm{a}$ \\
\hline M. ferrea & $\mathrm{C}$ & $7.9(0.1) \mathrm{a}$ & $7.3(0.2) \mathrm{a}$ \\
\hline M. nagassarium & $\mathrm{C}$ & $8.2(0.3)$ a & $7.0(0.4) \mathrm{a}$ \\
\hline LO & A & $28.7(0.6) \mathrm{a}$ & $26.7(0.3) \mathrm{a}$ \\
\hline D. zeylanicus & B & $22.5(0.7) \mathrm{a}$ & $18.3(0.5) b$ \\
\hline D. hispidus & $\mathrm{C}$ & $7.9(0.2) \mathrm{a}$ & $8.1(0.2) \mathrm{a}$ \\
\hline 1. ferrea & $\mathrm{C}$ & $8.0(0.2) \mathrm{a}$ & $8.1(0.2)$ a \\
\hline M. nagassarium & & & \\
\hline
\end{tabular}




\section{Table 4 : Lower epidermal cell thickness}

Data are means (in $\mu \mathrm{m}$ ) for different leaves, with standard errors in parentheses. A lower case a after one figure and $b$ after the other denotes a significant difference between the soil-moisture treatments in the same species and light treatment. The capital letters before the figures denote differ-ences between species in each light treatment. Species with the same letter are not significantly different.

\begin{tabular}{|c|c|c|c|}
\hline & & Dry & Moist \\
\hline \multicolumn{4}{|l|}{ FU } \\
\hline D. zeylanicus & A & $15.4(0.6) \mathrm{a}$ & $13.4(0.3) b$ \\
\hline D. hispidus & B & $11.2(0.2) \mathrm{a}$ & $10.7(0.3) \mathrm{a}$ \\
\hline M. ferrea & $\mathrm{C}$ & $8.6(0.3)$ a & $9.1(0.1) \mathrm{a}$ \\
\hline M. nagassarium & $\mathrm{D}$ & $5.9(0.9) \mathrm{a}$ & $5.3(0.1) \mathrm{a}$ \\
\hline \multicolumn{4}{|l|}{ FE } \\
\hline D. zevlanicus & A & $13.8(0.6) \mathrm{a}$ & $13.4(0.1) \mathrm{a}$ \\
\hline D. hispidus & B & $11.2(0.3) \mathrm{a}$ & $10.8(0.3) \mathrm{a}$ \\
\hline M. ferrea & $\mathrm{C}$ & $9.8(0.4) \mathrm{a}$ & $10.0(0.3) \mathrm{a}$ \\
\hline M. nagassarium & $\mathrm{D}$ & $6.0(0.0) \mathrm{a}$ & $5.6(0.3) \mathrm{a}$ \\
\hline \multicolumn{4}{|l|}{ OE } \\
\hline D. zeylanicus & A & $14.5(0.9) \mathrm{a}$ & $12.8(0.3) \mathrm{a}$ \\
\hline D. hispidus & $\mathrm{B}$ & $12.8(0.3) \mathrm{a}$ & $11.8(0.5) \mathrm{a}$ \\
\hline M. ferrea & $\mathrm{B}$ & $11.9(0.2) \mathrm{a}$ & $10.7(0.3) b$ \\
\hline M. nagassarium & & NA & $5.4(0.1)$ \\
\hline \multicolumn{4}{|l|}{ FS } \\
\hline D. zeylanicus & A & $17.9(0.9) \mathrm{a}$ & $15.6(0.6) \mathrm{b}$ \\
\hline D. hispidus & B & $12.8(0.3) \mathrm{a}$ & $11.8(0.5) \mathrm{a}$ \\
\hline M. ferrea & B & $12.6(0.5) \mathrm{a}$ & $11.9(0.3) \mathrm{a}$ \\
\hline M. nagassarium & $\mathrm{C}$ & $6.3(0.2) \mathrm{a}$ & $6.3(0.1) \mathrm{a}$ \\
\hline \multicolumn{4}{|l|}{ SO } \\
\hline D. zeylanicus & A & $14.3(0.7) \mathrm{a}$ & $13.6(0.3) \mathrm{a}$ \\
\hline D. hispidus & B & $10.8(0.4) \mathrm{a}$ & $11.5(0.7) \mathrm{a}$ \\
\hline M. ferrea & $\mathrm{B}$ & $11.7(0.1) \mathrm{a}$ & $10.9(0.6) \mathrm{a}$ \\
\hline M. nagassarium & $\mathrm{C}$ & $5.6(0.5) \mathrm{a}$ & $5.3(0.2) \mathrm{a}$ \\
\hline \multicolumn{4}{|l|}{ LO } \\
\hline D. zeylanicus & A & $15.5(0.7) \mathrm{a}$ & $15.4(0.2)$ a \\
\hline D. hispidus & B & $12.4(0.1) \mathrm{a}$ & $12.6(0.2) \mathrm{a}$ \\
\hline M. ferrea & C & $11.9(0.2) \mathrm{a}$ & $11.3(0.4) \mathrm{a}$ \\
\hline M. nagassarium & $\mathrm{D}$ & $5.7(0.1) \mathrm{a}$ & $6.1(0.3) \mathrm{a}$ \\
\hline
\end{tabular}


Table 5 : Lower epidermal cell layer thickness of the two Dipterocarpus species

Data are means (in $\mu \mathrm{m}$ ) from different leaves with standard errors in parentheses. A lower case a after one figure and $b$ after the other denotes a significant difference between the soil-moisture treatments in the same species and light treatment; species with the same letter are not significantly different. Similarly, the capital A and B before the figures denote differences between species in each light treatment.

\begin{tabular}{|c|c|c|c|c|}
\hline & \multicolumn{4}{|c|}{$\begin{array}{l}\text { Dry } \\
\text { Moist }\end{array}$} \\
\hline \multicolumn{5}{|l|}{ OE } \\
\hline D. zeylanicus & $D$. & A & $23.4(0.6) \mathrm{a}$ & $24.2(0.6) \mathrm{a}$ \\
\hline hispidus & & $\mathrm{B}$ & $21.3(0.3) a$ & $20.3(0.5) a$ \\
\hline \multicolumn{5}{|l|}{ FS } \\
\hline D. zeylanicus & $D$. & A & $29.4(1.0) a$ & $26.2(0.6) \mathrm{a}$ \\
\hline hispidus & & B & $23.1(0.6) \mathrm{a}$ & $19.6(0.2) \mathrm{b}$ \\
\hline \multicolumn{5}{|l|}{ SO } \\
\hline D. zeylanicus & $D$. & A & $24.9(0.8) a$ & $22.9(0.2) \mathrm{a}$ \\
\hline hispidus & & B & $18.3(0.3) a$ & $17.3(0.4) \mathrm{a}$ \\
\hline \multicolumn{5}{|l|}{ LO } \\
\hline D. zeylanicus & $D$. & A & $27.1(0.6) a$ & $28.2(0.9)$ \\
\hline hispidus & & $\mathrm{B}$ & $21.0(0.1) a$ & $20.7(0.6)$ \\
\hline
\end{tabular}

Table 6 shows palisade cell heights. Since the palisade cell stnucture largely depends upon the intensity of light (Simon et al., 1990), it was not surprising that the palisade cell height increased with increasing light intensity and varied between treatments as follows: $\mathrm{FS}>\mathrm{LO}>\mathrm{OE}>\mathrm{SO}>\mathrm{FE}>\mathrm{FU}$. Some significant differences were also apparent between species within a given light treatment. For palisade layer thickness there was only one significant difference (in treatment $O E$ ) between species in the same light treatment: the results for the dipterocarps are shown in Table 7. The Mesua species had greater palisade cell height than the dipterocarps. Where there were significant differences, $M$. ferrea had the greatest cell height, followed by $M$. nagassarium, $D$. zevlanicus, and $D$. hispidus. There were only a few significant differences in cell layer thickness between the different soil-moisture treatments.

While the Mesua species did not show this feature, the dipterocarps were observed to have several palisade cells stacked up on each other. The occurrence of this phenomenon increased with increasing light intensity; this explains why for both species the thickest cell layers were in the FS treatment. This double stacking phenomenon did not occur as a continuous layer. The proportion of double layering was 
therefore also recorded (Table 8): it increased with increasing light. In all treatments $D$. zeylanicus had a significantly higher proportion than $D$. hispidus.

Table 6 : Palisade cell depth

Data are means (in $\mu \mathrm{m}$ ) from different leaves, with standard errors in parenthescs. A lower case a after one figure and $b$ after the other denotes a significant difference between the soil-moisture treatments in the same species and light treatment. The capital letters before the figures denote differences between species in each light treatment. Species with the same letter are not significantly different.

\begin{tabular}{|c|c|c|c|}
\hline & & Dry & Moist \\
\hline \multicolumn{4}{|l|}{ FU } \\
\hline D. zeylanicus & $\mathrm{A}$ & $31.0(0.9) \mathrm{a}$ & $31.1(0.9) a$ \\
\hline D. hispidus & $B$ & $26.0(1.6) \mathrm{a}$ & $28.6(0.6) a$ \\
\hline W. ferrea & A & $33.1(0.6) \mathrm{a}$ & $34.9(1.3) \mathrm{a}$ \\
\hline M. nagassaritum & A & $34.0(1.0) \mathrm{a}$ & $31.8(0.7) a$ \\
\hline \multicolumn{4}{|l|}{$\mathbf{F E}$} \\
\hline D. zeylanicus & $\mathrm{B}$ & $35.6(0.5) \mathrm{a}$ & $33.8(0.3) b$ \\
\hline D. hispidus & C & $32.1(1.4) \mathrm{a}$ & $31.4(0.2) a$ \\
\hline M. ferrea & $A$ & $38.4(0.7) \mathrm{a}$ & $37.3(0.8) \mathrm{a}$ \\
\hline M. magassarium & $\mathrm{AB}$ & $37.1(0.7) \mathrm{a}$ & $36.2(0.5) a$ \\
\hline \multicolumn{4}{|l|}{ OE } \\
\hline D. zeylanicus & $\mathrm{B}$ & $35.8(1.2) \mathrm{a}$ & $39.2(1.2) \mathrm{a}$ \\
\hline D. hispidus & $\mathrm{C}$ & $31.8(0.7) a$ & $33.3(1.1)$ a \\
\hline M. ferrea & A & $45.6(0.2) \mathrm{a}$ & $39.9(1.3) \mathrm{b}$ \\
\hline 1. nagassarium & A & NA & $44.9(1.3)$ \\
\hline \multicolumn{4}{|l|}{ FS } \\
\hline D. zeylanicus & B & $40.8(0.8) \mathrm{a}$ & $42.7(1.0) \mathrm{a}$ \\
\hline D. hispidus & $\mathrm{BC}$ & $37.6(1.6) a$ & $38.4(2.4) \mathrm{a}$ \\
\hline M. ferrea & $\mathrm{AB}$ & $46.7(2.2) \mathrm{a}$ & $46.2(1.8) \mathrm{a}$ \\
\hline M. nagassarium & A & $51.8(0.5) \mathrm{a}$ & $43.2(0.0) b$ \\
\hline \multicolumn{4}{|r|}{$325(15)$} \\
\hline D. zeylanicus & $\mathrm{C}$ & $30.9(1.2) \mathrm{a}$ & $32.5(1.5) \mathrm{a}$ \\
\hline D. hispidus & C & $31.5(0.4) \mathrm{a}$ & $32.7(0.3) \mathrm{a}$ \\
\hline M. ferrea & A & $40.3(0.2) \mathrm{a}$ & $38.1(0.4) b$ \\
\hline M. nagassarium & B & $36.0(0.9) \mathrm{a}$ & $34.2(0.1) \mathrm{a}$ \\
\hline $383(1)$ & $\mathrm{AB}$ & $37.8(2.3) \mathrm{a}$ & $38.3(1.1) \mathrm{a}$ \\
\hline $\begin{array}{l}\text { D. zeylanicus } \\
\text { D. hispidus }\end{array}$ & $\mathrm{B}$ & $36.7(1.6) \mathrm{a}$ & $33.9(0.6) \mathrm{a}$ \\
\hline M. ferrea & A & $44.5(1.4) \mathrm{a}$ & $39.5(0.4) b$ \\
\hline M. nagassarium & A & $42.1(1.2) \mathrm{a}$ & $38.2(0.5) b$ \\
\hline
\end{tabular}


Table 7 : Palisade cell layer thickness of the two Dipterocarpus species

Data are means (in $\mu \mathrm{m}$ ) from different leaves with standard errors in parentheses. A lower case $a$ after one figure and $b$ after the other denotes a significant difference between the soil-moisture treatments in the same species and light treatment. Similarly, the capital A and B before the figures denote differences between species in each light treatment. Species with the same letter are not significantly different.

\begin{tabular}{|c|c|c|c|c|}
\hline & & & Dry & Moist \\
\hline $\begin{array}{l}\text { OE } \\
\text { D. zeylanicus } \\
\text { hispidus }\end{array}$ & D. & $\begin{array}{l}A \\
B\end{array}$ & $\begin{array}{l}57.5(1.6) \mathrm{a} \\
52.8(1.0) \mathrm{a}\end{array}$ & $\begin{array}{l}61.9(0.9) \mathrm{a} \\
54.2(1.5) \mathrm{a}\end{array}$ \\
\hline $\begin{array}{l}\text { FS } \\
\text { D. zeylanicus } \\
\text { hispidtus }\end{array}$ & D. & $\begin{array}{l}\mathrm{A} \\
\mathrm{A}\end{array}$ & $\begin{array}{l}63.6(0.8) \mathrm{a} \\
57.9(1.3) \mathrm{a}\end{array}$ & $\begin{array}{l}56.3(5.3) \mathrm{a} \\
60.6(2.3) \mathrm{a}\end{array}$ \\
\hline $\begin{array}{l}\text { SO } \\
\text { 1). zeylanicus } \\
\text { hispiduss }\end{array}$ & D. & $\begin{array}{l}\mathrm{A} \\
\mathrm{A}\end{array}$ & $\begin{array}{l}52.2(1.4) \mathrm{a} \\
49.2(0.5) \mathrm{a}\end{array}$ & $\begin{array}{l}55.6(1.7) \mathrm{a} \\
52.7(1.0) \mathrm{b}\end{array}$ \\
\hline $\begin{array}{l}\text { LO } \\
\text { D. zeylanicus } \\
\text { hispidus }\end{array}$ & D. & $\begin{array}{l}A \\
A\end{array}$ & $\begin{array}{l}59.7(1.8) \mathrm{a} \\
58.6(2.3) \mathrm{a}\end{array}$ & $\begin{array}{c}57.9(0.6) \mathrm{a} \\
50.2(0.3) \mathrm{b}\end{array}$ \\
\hline
\end{tabular}

Table 8 : Proportion of layering of palisade cells for the two Dipterocarpus species Data are means from different leaves, with standard errors in parentheses. A lower case $a$ after one figure and $b$ after the other denotes a significant difference between the soilmoisture treatments in the same species and light treatment. Similarly, the capital A and $B$ before the figures denote differences between species in each light treatment. Species with the same letter are not significantly different.

\begin{tabular}{|c|c|c|c|c|}
\hline & & & Dry & Moist \\
\hline \multicolumn{5}{|l|}{ OE } \\
\hline D. zeylanicus & D. & A & $0.33(0.01) \mathrm{a}$ & $0.31(0.02) b$ \\
\hline hispidus & & A & $0.30(0.03) \mathrm{a}$ & $0.28(0.01) b$ \\
\hline \multicolumn{5}{|l|}{ FS } \\
\hline D. zeylanicus & D. & A & $0.40(0.01) \mathrm{a}$ & $0.38(0.01) \mathrm{a}$ \\
\hline hispidus & & B & $0.35(0.02) \mathrm{a}$ & $0.34(0.01) \mathrm{a}$ \\
\hline \multicolumn{5}{|l|}{ So } \\
\hline 1). zeylamicus & D. & A & $0.27(0.02) a$ & $0.26(0.01) \mathrm{a}$ \\
\hline hispidus & & B & $0.22(0.01) \mathrm{a}$ & $0.24(0.02) a$ \\
\hline \multicolumn{5}{|l|}{ LO } \\
\hline D. zeylamicus & $D$. & A & $0.30(0.01) \mathrm{a}$ & $0.32(0.02) \mathrm{a}$ \\
\hline hispidtus & & B & $0.29(0.01) \mathrm{a}$ & $0.27(0.01) \mathrm{a}$ \\
\hline
\end{tabular}




\section{Discussion}

In combination, an array of anatomical characteristics can partly determine the morphological light and drought tolerance of a species (Ashton \& Berlyn, 1992). The effect of light on the leaf morphology of woody angiosperms is well-known. Several investigators have reported that anatomical changes in the leaves, such as stomatal frequency, leaf-blade thickness, and other cell component dimensions, vary with exposure to light (Cutter, 1978: Simon et al., 1990). For example, stomatal frequency increases with increasing light intensity. This variation in stomatal frequency in differing light environments has been attributed to change in leaf size. Greater light intensities promote reduction in leaf size in order to prevent desiccation (Ciha \& Brun, 1975). However this is not true for all species. For Shorea, section Doona, at least two of the species show little change in leaf size between light environments (Ashton, 1995). Stomatal frequency can be used to gauge drought tolerance of species with similar morphology. (Ashton \& Berlyn, 1992). For example, because Dipterocarpus hispidus has greater stomatal frequency than D. zevlanicus it could be deduced that the former is less tolerant. Similarly M. ferrea, with a greater stomatal frequency, could be less drought tolerant than M. nagassrium.

The amount of light can also have a direct influence on blade thickness (Simon et al., 1990). For the study species this may be due to increases in mesophyll and palisade tissue in the brighter light treatments. All spongy mesophyll, palisade and epidermal cells were densely packed in the high light treatments. which reduced air space within the leaf. This phenomenon can increase leaf-blade thickness and also promote greater water-use efficiency. Leaf-blade thickness can also be used as a gauge for determining both light and drought tolerance of similar species (Ashton \& Berlyn, 1992). Dipterocarpus zeylanicus, which has a thicker leaf blade than D. hispidus could be considered more light and drought tolerant. Similarly, although in most comparisons no difference could be found between the Mesua species, for the SO and LO treatments, $M$. ferrea had a thicker leaf blade, suggesting that it is the more light and drought tolerant of the two.

Anatomical differences between species are also apparent for epidermal cell dimensions and epidermal layer thicknesses; the upper epidermal layer is the onc most exposed to direct radiation. Upper epidermal cell dimensions can also indicate light tolerance (Ashton \& Berlyn, 1992). In this study D. zeylanicus was found to have upper epidermal cells of greater height than those of $D$. hispidus. Mesua ferrea had lower epidermal cells that were papillated and with sunken stomata - a characteristic that would make it more drought tolerant than M. nagassarium. Both Dipterocarpus species had double rows of cells in the lower epidermal layer; Mesua did not show this feature. It should promote greater water-use efficiency.

Both the palisade cell height and layer thickness increased with increase in exposure to light in all four species. Increased palisade cell layers can reduce the spaces in the leaf by their dense packing as compared with that of the irregularly shaped spongy mesophyll cells. This dense packing in high light environments can promote greater 194 
capture of light radiation and greater protection from desiccation. The greater cell height in $D$. zevlanicus indicates that it is more light demanding than $D$. hispidus. Stacking of palisade cells upon each other was seen only in Dipterocarpus. This phenomenon was observed only in the more intensive light treatments and its occurrence declined in the order $\mathrm{FS}>\mathrm{OE}>\mathrm{LO}>\mathrm{SO}$. It was greater in D. zeylanicus than in D. hispidus, which suggests that the former could be more efficient in capturing light.

Available soil moisture is also important in determining leaf anatomy and morphology (Young \& Gicse, 1990). In this study stomatal frequency was greater in the dry-soil treatment in only a few instances, most notably in D. zeylanicus. In these dry conditions leaves exhibited more xerophytic characteristics, that are similar to those of leaves exposed to large amounts of desiccating radiation. When there are more stomata the distances between them are less and the amount of water transpired is greater; these factors increase the humidity of the leaf surface. The moisture gradient between the leaf and its surrounding enviromment is therefore reduced and there is a net reduction in water loss. In this experiment, in the dry-soil treatment, water was added to bring the soil to full capacity whenevet the moisture content reached less than $30 \%$. We speculate that under these conditions, except in the case of D. zeylanicus, the species were enabled to withstand droughty conditions by controlling the stomatal apertures.

In most cases blade thickness. upper and lower epidermal layer thicknesses, and palisade cell height did not change significantly with the availability of soil moisture.

In conclusion. this study demonstrated that the seedlings of species classified as latesuccessional canopy trees have morphological and anatomical leaf characteristics that change with light and with soil-moisture availability. The greatest differences in dimensions were observed between light treatments rather than soil-moisture treatments. Of the two dipterocarps, D. zeylanicus, which had thicker leaf blades and greater height for the upper and lower epidermal and palisade cell layers, could be regarded as more light tolerant than D. hispidus. Its low stomatal frequency and greater differences under the two soil-moisture treatments also suggest that D. zeylanicus is probably the more drought tolerant of the two. In Mesua most of the anatomical and morphological dimensions differed between the two species within the direct sun treatments (SO, LO). In these treatments the thicker leaf blade and greater palisade cell height of $M$. ferrea would suggest that it is more light tolerant than $M$. nagassarium, whereas the lower stomatal frequency in $M$. nagassarium would perhaps make it the more drought tolerant of the two species.

Comparing genera, the greater blade thickness and palisade cell height of the Mesua species prompts speculation that they are more light demanding than the dipterocarps. As regards stomatal frequency $D$. hispidus had the most, and D. zeylanicus the least, while the Mesua species had an intermediate count - which would make D. zeylanicus the most drought tolerant. However, some anatomical features are genus specific. Examples such as double layering of palisade and lower epidermal cells, the shape of palisade cells, and stomatal size, make intergeneric comparisons difficult. Also, for 
example, $M$. ferrea has sunken stomata with an external air-chamber, and $D$. hispidus las hairs on the leaf surface. These facts can confuse even comparisons within genera, and it is important to take them into account when speculating on species differences in light and drought tolerance based on leaf morphology.

\section{Acknowledgements}

Thanks are due to the Forest Department, Sri Lanka. for allowing us to use the field station at the Sinharaja MAB in order to carry out this experiment. Both financial support and the provision of use of facilities for this study were provided by the Forestry Unit, University of Sri Jayawardenapura.

\section{References}

Ashton, P.M.S. (1992). Some measurements of the microclimate in a Sri Lankan rain forest. Agricultural and Forestry Meteorology 59, 217-235.

Ashton, P.M.S. (1995). Seedling growth of co-occurring Shorea species in the simulated light environments of a rain forest. Forest Ecology and Management 72 , $1-12$.

Ashton. P.M.S. and Berlyn, G.P. (1992). Leaf adaptations of some Shorea species to sun and shade. New Phytologist 121, 587-596.

Ashton, P.M.S., Gunatilleke, C.V.S. and Gunatilleke, I.A.U.N. (1993). A shelterwood method of regeneration for sustained timber production in Mesua-Shorea forest of southwest Sri Lanka. In Ecology and landscape management in Sri Lanka (Eds. Erdelen, W., Preu, C, Ishwaran, N. and Madduma Bandara. C.M.). Weikershcim. Germany, Margraf Scientific Books. Pp. 255-274.

Ashton, P.S. and Gunatilleke, C.V.S. (1987). New light on the plant geography of Ceylon, 1 Historical plant geography. Journal of Biogeography 14, 249-285.

Berlyn, G.P. and Miksche J.P. (1976). Botanical microtechnique and cytochemistrv. Ames, lowa, lowa State University Press.

Bouyocos, G.P. (1953). More desirable plaster of Paris moisture blocks. Journal of Soil Science 76, 447-451.

Bouyocos, G.P. (1972). A new electrical soil-moisture measuring unit. Journal of Soil Science 114, 493.

Carpenter, S.B. and Smith, N.D. (1975. A comparative study of leaf thickness among southern Appalachian hardwoods. Canadian Journal of Botany 59, 1393-1396.

Ciha, A.J. and Brun, W.A. (1975). Stomatal size and frequency in soybeans. Crop Science 15, 309-313.

Cutter, E.G. (1978). Plant anatomy Part l, Cells and tissues. 2nd ed. London, Willian Clowes and Sons,

Dassanayake, M.D. (1980). A revised handbook to the flora of Ceylon, Vol.l. New Delli, Amerind.

De Rosayro, R.A. (1942). The soils and ecology of the wet evergreen forests of Ceylon. Tropical Agriculture 98, 78-180.

FAO (1985). Dipterocarps of South Asia. Bangkok, FAO Regional Office for Asia and the Pacific. 
Fetcher. N.. Strain. B.R. and Oberbauer. S.F. (1983). Effects of light regimes on the growh. Ieaf morphology and water relations of secdlings of two species of tropical trees. Oecologia 58, 314-319.

Heichel. G.H. (1971). Stomatal frequencies and resistances in two maize varieties differing in photosynthetic capacity. Journal of Experimental Botany 22 (72) 644649

Jackson, L.W.R. (1966). Effect of shade on leaf structure of deciduous tree species. Ecologv 48, 498-499.

Keller, R.A.. Tsujita. M.J. and Ormrod D.P. (1987). Liglı acclimatization effects on Japanese maple of interior use. Hortscience 22 (5) 929-931.

Kramer, P.J. (1983). Water relations of plants. New York. Academic Press.

Loach, K. (1967). Shade tolerance in tree seedlings. New Phytologist 66, 607-621.

Metcalfe. C.R. and Chalk, L. (1965). Anatomy of the Dicotyledons, Vol 1. Oxford, Clarendon Press.

Nobel, P.S. (1977). Internal leaf area cellular $\mathrm{CO}_{2}$ resistance: photosynthetic implications of variations with growth conditions and plant species. Physiologia Plantarum 40, 137-144.

Popma, J. and Bongers, F. (1988). The effect of canopy gaps on growth and morphology of seedlings of rain forest species. Oecologia 75 625-632.

Ray, A.A. (1982). SAS user's guide. Cary, North Carolina. Statistical Analysis Systems Institute lnc.

Simon, E.W.. Dormer, K.J. and Hartshorne, J.N. (1990). Lowson's Text Book of Botany. New Dellii. Universal Book Stall.

Transeau, E.N., Samson, H.C.and Tiffany, L.H. (1940). Text Book of Botany. New York. Harper and Sons.

Vogel, S. (1968). Sun leaves and shade leaves: differences in convective heat dissipation. Ecology 49 (6) 10168.

Wilson, D and Cooper,J P (1969) Effect of light intensity during growth on leaf anatomy and subsequent light - saturated photosynthesis among contrasting Lolium genotypes New phytologist 68: 1125-1135

Young. R.A. and Giese, R.L. (1990). Introduction to For. Sci., USA. 